\title{
小児用補助人工心臓のための小型磁気浮上モータの第一試作
}

\section{Prototype of Miniaturized Magnetically Levitated Motor for Paediatric VAD}

\author{
大森 直樹 ${ }^{* 1}$ (学生員), 増澤 徹 ${ }^{* 1}$ (正員), 長 真啓 ${ }^{* 1}$ (学生員), 巽 英介 ${ }^{* 2}$
}

Naoki OMORI (Stu. Mem.), Toru MASUZAWA (Mem.), Masahiro OSA (Stu. Mem.),Eisuke TATSUMI

\begin{abstract}
A miniaturized magnetically levitated motor which can actively control 5-degrees of freedom (5-DOF) of impeller postures has been newly developed for a paediatric ventricular assist device (VAD). Developed motor consists of a top stator, a bottom stator and a levitated impeller that is set between the both stators. The diameter and the height of the motor are $28 \mathrm{~mm}$ and $41 \mathrm{~mm}$, respectively. Magnetic field analysis with finite element method was performed in order to design the geometry of motor permanent magnets and a stator. Corners of the motor permanent magnets were cut to produce sinusoidal distribution of magnetic flux density and to reduce the cogging torque. The developed maglev motor produces sufficient suspension force and rotates the levitated impeller up to a rotating speed of $6000 \mathrm{rpm}$ with sufficient posture control performance.
\end{abstract}

Keywords: 5-DOF, self-bearing motor, paediatric, ventricular assist device.

\section{1 緒言}

現在，重症心不全患者の治療として心臓移植が行わ れており，心臓移植までの橋渡しとして自己心臓に並 列に装着してその心機能を補助する補助人工心臓が適 用されている[1-3]。2010 年 7 月の臓器移植法の改正に より，15 歳以下の小児にも心臓移植が法的に可能にな ったが，現状では小児に埋め込み可能な補助人工心臓 は存在しない。そのため, (社)臓器移植ネットワーク に登録している 10 歳未満の小児の待機患者 10 人に対 し，日本国内での小児の心臓移植件数は 2012 年の 1 件のみにとどまっている。日本国内の小児患者へのド ナ一不足と共に, 有効な循環補助手段が存在しないこ とは深刻な医療問題であり, 小児用の補助人工心臓の 開発が望まれている[4-6]。一方，体内埋め込み型の人 工心臓は高い生体適合性と年オーダーの機械的寿命が 必要であり，機械的摺動部を撤廃できる磁気浮上モ一 タを用いた補助人工心臓が開発されている[7-10]。しか し，補助人工心臓を小児に適用するには更なるデバイ スの小型化が必要であるが, 小型化による磁気浮上モ 一タの磁気吸引力と回転トルクの低下が問題となる。

更に磁気浮上系の低剛性化に伴い多自由度の能動制御 による系の安定化が必要となる。一般に磁気浮上モー

連絡先：増澤 徹, $\bar{\top} 316-8511$ 茨城県日立市中成沢町 4-12-1, 茨城大学工学部機械工学科, e-mail: masuzawa@mx.ibaraki.ac.jp

*1 茨城大学 ${ }^{* 2}$ 国立循環器病研究センター

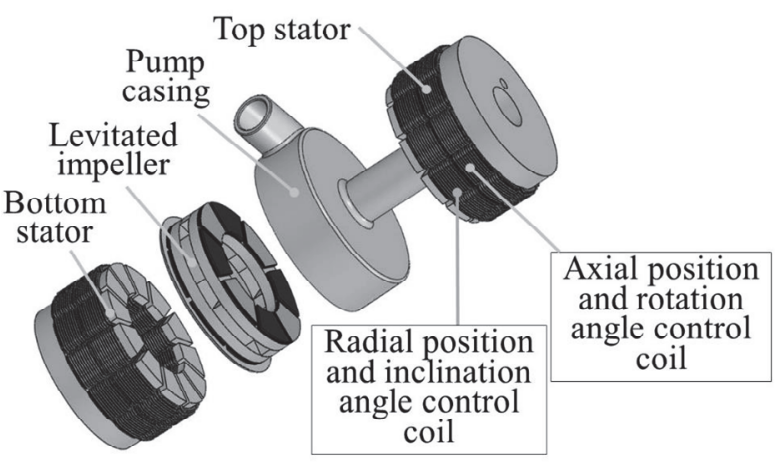

Fig. 1 Structure of 5-DOF control paediatric VAD.

タで多自由度の制御を行う場合は，制御自由度ごとに 磁気軸受が必要となり, 制御自由度の数だけ大型化す る。小型化と磁気浮上安定化のトレードオフ問題を解 決するために，我々は2つの磁気浮上モータステータ でインペラの 5 自由度および回転を能動的に制御可能 な新しいアキシャル型セルフベアリングモータを提案 する。今回，プロトタイプのアキシャル型磁気浮上モ ータを設計，製作し，評価を行ったので報告する。

\section{2 方法}

\section{1 小北用補助人工心臓の概要}

提案する小览用補助人工心臓をFig. 1に示す。小型遠 心ポンプにアキシャル型セルフベアリングモータを組 み込むことで小児用人工心臓を構成する。小児用補助 人工心臓は上部ステータ, 下部ステータ, 浮上インペ 


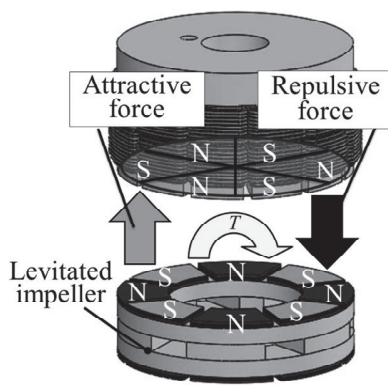

(a) Tilt angle control.

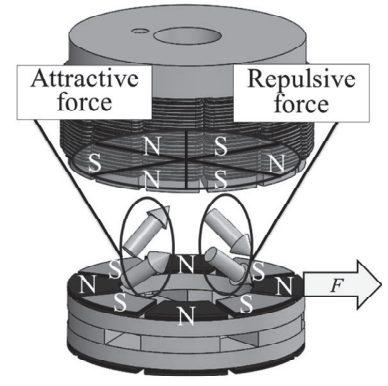

(b) Radial position control.
Fig. 2 Principle of tilt angle and radial position control.

ラ，ポンプケーシングから成る。磁気浮上モータは磁 気軸受とモータを一体化した同一形状の磁気ステータ を上下に配置するアキシャル型セルフベアリングモー タである。1 2 本の突極に軸方向位置・回転制御用コイ ルと径方向位置・傾き制御用コイルの 2 種類を配置す ることでロータの 5 自由度および回転を能動的に制御 する。ロータは上下両表面に 8 極の永久磁石を配置す る。浮上インペラは羽根を表面に永久磁石を設置した ロータヨークで上下から挟みこみ，クローズドインペ ラとした。インペラとポンプケーシング内壁の軸方向 のクリアランスを狭血液流路における血球破壊を回避 するために $0.3 \mathrm{~mm}$ とし, ポンプケーシングと血液流 路を構成するために, 磁気浮上モータのエアギャップ を $1.5 \mathrm{~mm}$ と広くとっている。小児用人工心臓の目標 駆動回転数域は $500 \mathrm{rpm}$ から $4000 \mathrm{rpm}$ であり, 本回転 数領域においてポンプクリアランスの $10 \%$ 以下の振 動振幅で浮上インペラを磁気支持可能であることを目 標とした。

\section{2 磁気浮上制御原理}

\subsection{1 軸方向位置・回転角度制御原理}

本磁気浮上モータはアキシャルギャップ表面磁石 同期モータを基本にしている。モータステータに集中 巻きした軸方向位置・回転角度制御用コイルで 3 相 8 極の回転磁界を発生させる。ベクトル制御を用いて軸 方向吸引力および回転トルクを独立に調節し, 軸方向 位置と回転速度を制御する。 $\mathrm{U}$ 相，V 相，W 相からな る 3 相交流は, ステータに固定された座標系の $\alpha$ 相, $\beta$ 相の 2 相交流に等価変換される。 $\alpha \beta$ 座標をロータと 同期して回転する $\mathrm{dq}$ 座標に変換することで, 3 相交流 は dq 座標系で静止したベクトルとして表される。 $\mathrm{d}$ 軸 電流と $\mathrm{q}$ 軸電流から 3 相交流の波高值と位相を決定す

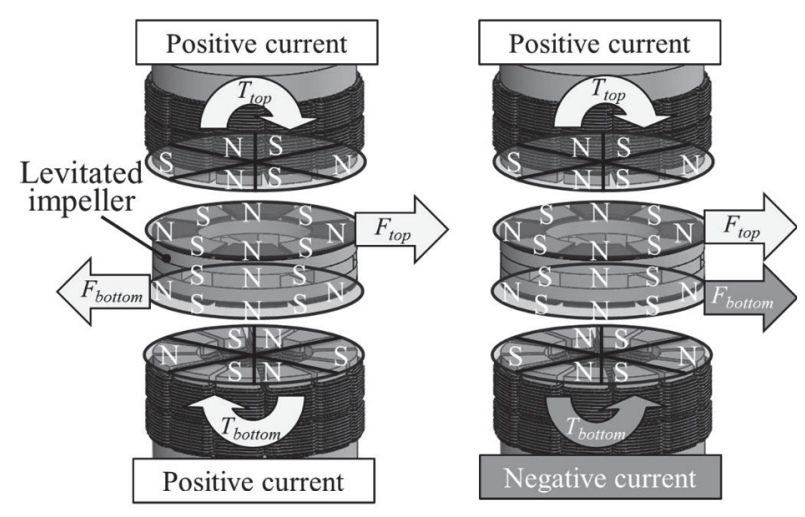

(a) Tilt angle control. (b) Radial position control.

Fig. 3 Principle of tilt restoring torque and radial force control.

る。ダブルステータ構造の場合，ロータに働く軸方向 吸引力 $F_{z}$ は上下で発生する軸方向吸引力の差になり, 回転トルク $T_{z}$ は上下で発生する回転トルクの和とな り，以下の式で表される。

$$
\begin{gathered}
F_{z}=\frac{\sqrt{6}\left(r_{2}^{2}-r_{1}^{2}\right) \pi}{2 \mu_{0}} B p \cdot \frac{\mu_{0} N I_{d}}{z} \\
T_{z}=-\sqrt{\frac{3}{2}} \frac{\left(r_{2}^{2}-r_{1}^{2}\right) \pi M z}{2 \mu_{0}} B_{p} \frac{\mu_{0} N I_{q}}{z}
\end{gathered}
$$

ここで, $r_{1}$ および $r_{2}$ はモータ内径およびモータ外径, $z$ はエアギャップ長, $M$ は永久磁石の極対数, $B_{p}$ は永久 磁石が発生する磁束密度の波高值, $\mathrm{N}$ はコイル巻き数, $I_{d}, I_{q}$ は励磁電流の $\mathrm{d}$ 軸成分, $\mathrm{q}$ 軸成分を示寸。本式か ら, 軸方向吸引力および回転トルクは回転角度に依存 せずに発生することが分かる。

\subsection{2 径方向位置・傾き角度制御原理}

径方向位置・傾き角度制御ではステータ極数をロー 夕極数 $\mathrm{P}$ に対して $\mathrm{P} \pm 2$ 極に励磁する $\mathrm{P} \pm 2$ 極理論を用 いて制御を行う。Fig. 2(a)に傾き復元トルクの発生原理 について示す。ロータ磁界を 8 極, 制御磁界を 6 極と した。図中, ロータ左端では, ロータ磁界の $\mathrm{N}$ 極と制 御磁界の $\mathrm{S}$ 極が吸引力を発生する磁極配置となるよう に向かい合う。一方, 図中, ロータの右端では, ロー 夕磁界の $\mathrm{N}$ 極と制御磁界の $\mathrm{N}$ 極が反発力を発生するよ うな磁極配置となるように向かい合う。これらの磁気 力により紙面時計回りに復元トルクが発生する。以下 にシングルステータの場合の径方向 X軸回りの傾き復 元トルク $T_{x}$ の理論式を示す。 

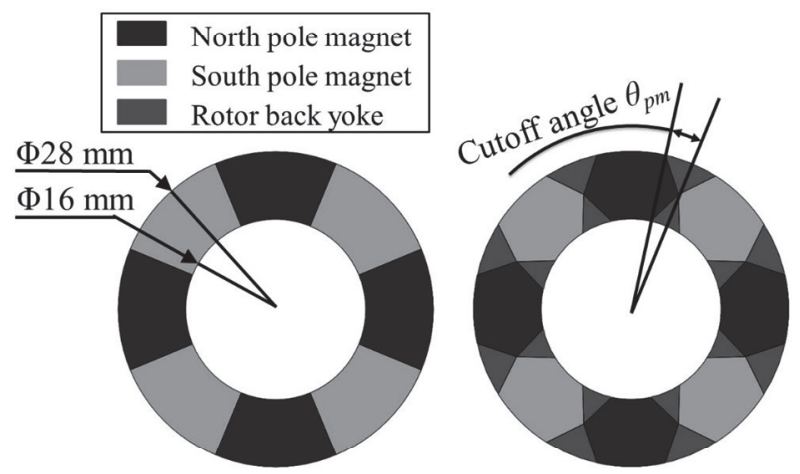

(a) Fan shape magnet.

(b) Hexagonal shape magnet.

Fig. 4 Schematic of permanent magnet.

$$
T_{x}=\frac{r_{2}^{3}-r_{1}^{3}}{6 z} \pi B_{p} B_{e}
$$

ここで $B_{e}$ はステータコイルが発生する磁束密度の波 高值を示す。本式から, 傾き復元トルクはロータの回 転角度に依存せずに発生することが分かる。今回，ア キシャルギャップモータで $\mathrm{P} \pm 2$ 極理論を適用すると， 復元卜ルクが発生するのと同時に径方向力が発生する ことを新たに発見して径方向位置制御に利用した[11]。 $\mathrm{P} \pm 2$ 極理論に基づきステータ電磁石が発生させる制 御磁界とそれにより発生する径方向磁気力について Fig. 2(b)に示す。ロータの左半分では, ロータ磁界の N 極と制御磁界の $\mathrm{S}$ 極が吸引力を発生する磁極配置とな るように向かい合う。一方, ロータの右半分では, 口 一夕磁界の $\mathrm{S}$ 極と制御磁界の $\mathrm{S}$ 極が反発力を発生する ような磁極配置となるように向かい合う。ロー夕磁界 と制御磁界の磁極配置によりロータに働く吸引力と反 発力はそれぞれ紙面右向きの半径方向成分を含むため, ロータには半径方向に磁気力が発生する。ダブルステ 一タ型とすることで, 傾き復元トルクおよび径方向力 を独立に制御する。ロータの Y 軸回りの傾きと X 軸方 向の径方向位置を制御する場合の制御原理についての 概略図をFig. 3に示す。Fig. 3(a)では上部ステータと下 部ステータに正方向の電流を励磁する。傾き復元トル クはロータ上面と下面においてそれぞれ時計回りに発 生し, 径方向磁気力はロータ上下において互いに打ち 消し合う方向に発生する。このため, 傾き復元トルク を発生することができる。Fig. 3(b)では上部ステータに 正方向の電流を励磁し, 下部ステータに負方向の電流 を励磁する。ロータの上面では時計回りの傾き復元卜 ルクが発生し, 下面では反時計回りの傾き復元トルク が発生するため傾き復元トルクは互いに打ち消し合う。

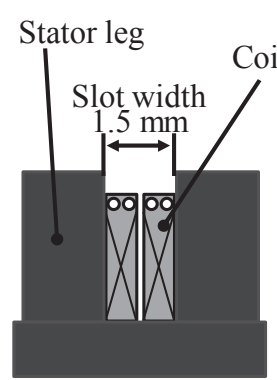

(a) Stator-1.

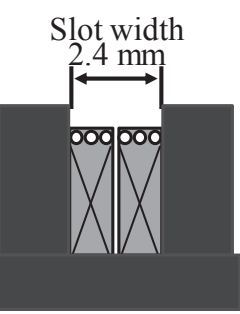

(b) Stator-2.

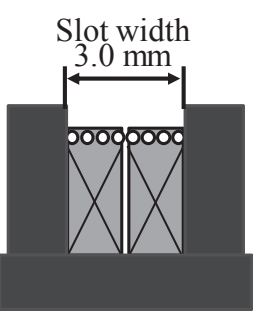

(c) Stator-3.
Fig. 5 Schematic of stator pole and electromagnetic coil.

Table 1 Stator pole surface area and coil turn number.

\begin{tabular}{l||c|c|c} 
& Stator-1 & Stator-2 & Stator-3 \\
\hline \hline $\begin{array}{l}\text { Stator pole } \\
\text { surface area }\left[\mathrm{mm}^{2}\right]\end{array}$ & 25.6 & 20.1 & 16.5 \\
\hline Coil turn number [turn] & 31 & 45 & 58
\end{tabular}

\section{3 磁場解析による小型磁気浮上モータの設計}

\section{3 .1 永久磁石形状の検討}

式(2)に示したトルク理論計算式はエアギャップ中 に発生する磁束密度が正弦波状に分布すると仮定して いる。そのため，回転トルクは回転角度に依存せずに 発生する。しかし，Fig. 4(a)に示寸永久磁石面積が大き い扇形永久磁石を用いると，エアギャップ中の磁束密 度は矩形波状に分布し，その高調波成分によりコギン グトルクが発生する。高調波成分は一般的な軸付きモ 一タでは騷音や振動の原因になるが, 磁気浮上モータ でも磁気浮上力, 回転トルクを変動させ, 磁気浮上性 能，回転制御性能に影響を与える。そこで，空間磁束 分布を正弦波に近づけ，磁束高調波成分を減らす永久 磁石形状の検討を行った。その形状をFig. 4(b)に示す。 有限要素法による 3 次元磁場解析を用いて永久磁石の 角を切除する角度を検討した。ここで, Fig. 3(b)に示す ように，永久磁石の角を切除した部分の角度を切除角 度 $\theta_{p m}$ と定義する。切除角度 $\theta_{p m}$ を $5 \mathrm{deg}, 10 \mathrm{deg}, 15 \mathrm{deg}$ とした時のエアギャップ中の磁束密度分布, 軸方向吸 引力, コギングトルクを推定した。非励磁状態でロー タを $1.25 \mathrm{deg}$ 毎に回転させる。

\subsection{2 ステータ突極形状の検討}

本磁気浮上人工心臓では, 浮上インペラはポンプ内 で軸方向に $\pm 0.3 \mathrm{~mm}$ の可動域を持ち, 全可動域におい て磁気浮上可能な力係数 (励磁電流 $0 \mathrm{~A}$ と $1 \mathrm{~A}$ での軸 


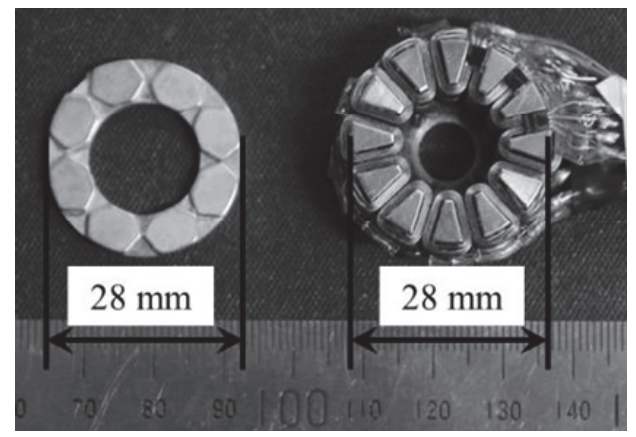

Fig. 6 Developed rotor and stator.

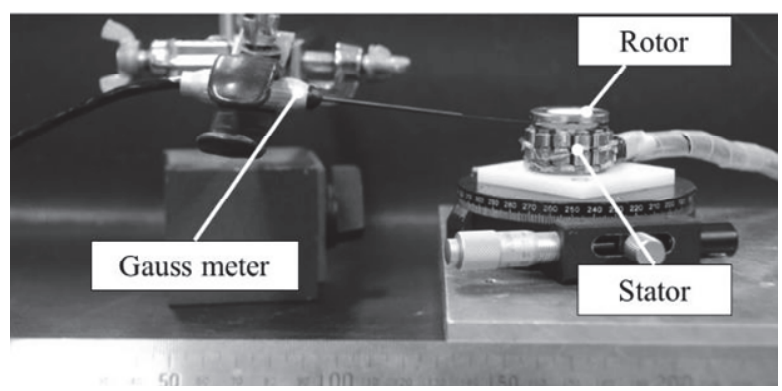

Fig. 7 Magnetic flux density measurement system.

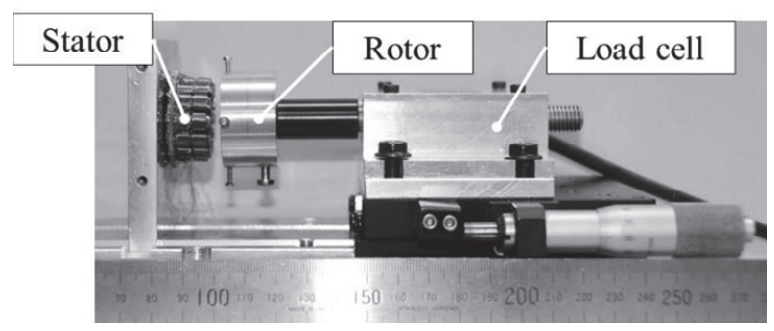

Fig. 8 Axial attractive force measurement system.

方向吸引力の差）が必要である。特にインペラがタッ チダウンしている時に永久磁石による磁気吸引力が最 大になり, 電磁石はその吸引力に打ち勝ってインペラ を浮上させなければならない。式(1)で示すように軸方 向吸引力および力係数はコイル巻き数に依存する。モ 一タを小型化しつつ力係数を増加させるためには, 各 突極間のスロット幅を広げてコイル巻き数を増やすこ とが有効であるが，各突極間のスロット幅を広げるこ とはステータ断面積の減少を招き, 軸方向吸引力の減 少, 磁気飽和を招くため, 本問題はトレードオフ問題 となる。よって, 有限要素法による 3 次元磁場解析を 用いてコイル巻き数およびステータ突極断面積を検討 した。Fig. 5にスロット幅の異なる 3 種類の突極幾何形 状を示す。Table 1に突極断面積とコイル巻き数を示す。 線径 $0.3 \mathrm{~mm}$ のコイル線を使用し, Stator-1 で径方向 2 層のコイル, Stator-2 で 3 層のコイル, Stator-3 で 4 層 のコイルを配置できる形状とした。ロータの可動範囲
(エアギャップが $1.5 \mathrm{~mm}$ (浮上中心) から $\pm 0.3 \mathrm{~mm}$ (ク リアランス幅)）の軸方向吸引力と力係数を推定した。 推定した力係数をもとに次式にてインペラがタッチダ ウンから浮上するために必要な励磁電流を求めた。

$$
I_{\text {Lev }}=\frac{F_{P M_{-} \text {Top }}-F_{P M_{-} \text {Bottom }}}{F_{E_{-} \text {Top }}+F_{E_{-} \text {Bottom }}}
$$

ここで, $I_{L e v}$ はタッチダウンから浮上に必要な電流, $F_{P M \_T o p}$ は上部ステータの永久磁石による軸方向吸引力, $F_{P M_{B} \text { Bottom }}$ は下部ステータの永久磁石による軸方向吸引 力, $F_{E_{-} T o p}$ は上部ステータによる力係数。 $F_{E_{-} \text {Bottom }}$ は下 部ステータによる力係数である。

\section{4 小型磁気浮上モータの製作と評価}

\subsection{1 小型アキシャル型セルフベアリングモータ}

3 次元磁場解析結果をもとに, 小型アキシャル型セ ルフベアリングモータ試作機を製作した。Fig. 6に製作 した浮上インペラヨークおよびステータを示す。ヨー クおよびステータの外形は $28 \mathrm{~mm}$ ，ステータ高さは $15.5 \mathrm{~mm}$ である。浮上インペラヨーク表面には永久磁 石切除角度 $10 \mathrm{deg}$, 永久磁石厚さ $1.0 \mathrm{~mm}$ のネオジウム 磁石（N48H）を貼り付けた。ステータは2.3.1 で述べ た Stator-3 を採用した。ステータ材料は製作の容易性 から磁性軟鉄 SUY-1 を使用し, コイル巻き数は 58 巻 とした。

\subsection{2 磁束密度分布, 軸方向吸引力測定}

Fig. 7に磁束密度分布測定装置を示す。ロータとステ 一タを向かい合わせて配置し, エアギャップは $1.5 \mathrm{~mm}$ とする。回転ステージでロータとステータを $2.5 \mathrm{deg}$ 毎に回転させ，ガウスメータでエアギャップ中の永久 磁石による磁束密度分布を測定した。Fig. 8に軸方向吸 引力測定装置を示す。励磁電流を-2 A から $2 \mathrm{~A}$ まで, エアギャップを $1 \mathrm{~mm}$ から $2 \mathrm{~mm}$ まで変化させて軸方 向吸引力をロードセルで測定した。

\section{4 .3 磁気浮上実験}

Fig. 9 亿磁気浮上実験機を示す。本磁気浮上実験機は ステータ，ロータおよび渦電流変位センサを保持する ためのセンサホルダで構成される。幅は $47 \mathrm{~mm}$, 高さ は $48 \mathrm{~mm}$ である。浮上ロータの可動域は軸方向位置に $\pm 0.3 \mathrm{~mm}$, 径方向位置に $\pm 0.5 \mathrm{~mm}$, 傾き角度に $\pm 1 \mathrm{deg}$ とした。Fig. 10に磁気浮上制御系の説明図を示す。本 磁気浮上モー夕は軸方向位置に配置された 3 個の渦電 


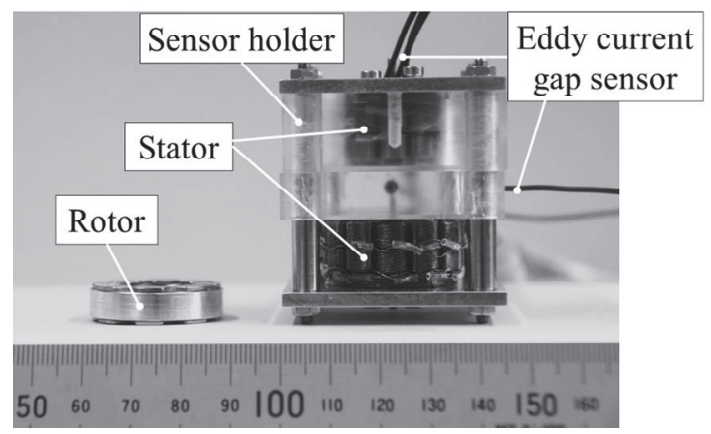

Fig. 9 Developed magnetically levitated motor.

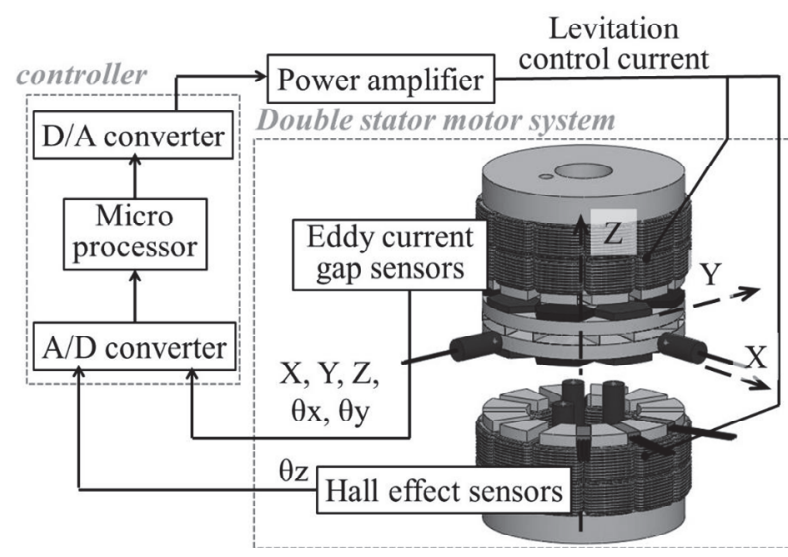

Fig. 10 Diagram of 5-DOF control and rotation.

流変位センサ（株式会社電子応用：PU-03A）により ロータの軸方向位置および傾き角度を, ロータ側面に 配置した 2 個の渦電流変位センサによりロータの径方 向位置を検出する。また，ステータスロットに配置し た 3 個のホールセンサによりロータの回転角度を検出 する。これらの検出結果からデジタル PID コントロー ラで指令制御電流を計算し，パワーアンプを介してス テータコイルに制御電流を流すことでロータの 5 自由 度および回転を能動的に制御する。

\section{3 結果·考察}

\section{1 磁場解析による小型磁気浮上モータの設計}

\section{1 .1 永久磁石形状の検討}

Fig. 11にエアギャップ中の磁束密度分布 (解析結果) を示す。比較対象として波高值が $0.4 \mathrm{~T}$ の正弦波（破 線）も載せた。扇形の永久磁石の角を切除することで 磁束密度の高調波が減少することを確認した。切除角 度 $5 \mathrm{deg}$ では磁束密度の高調波成分が大きいが, 切除 角度を $10 \mathrm{deg}, 15 \mathrm{deg}$ とすることで, 破線で示した正 弦波に近い波形を示した。ロータ回転により生じるコ ギングトルクおよび軸方向吸引力の脈動（解析結果）

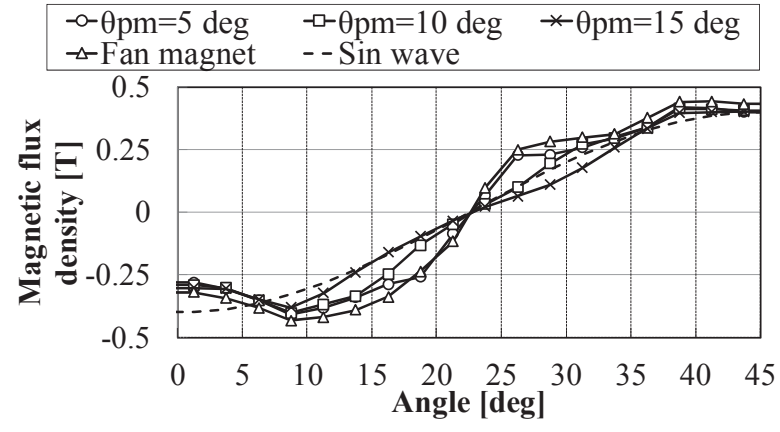

Fig. 11 Analysis result of magnetic flux density.

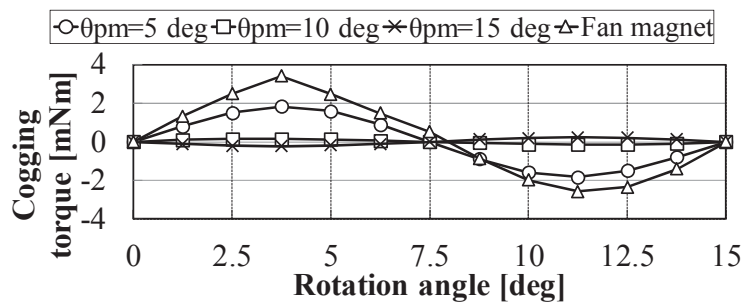

(a) Cogging torque.

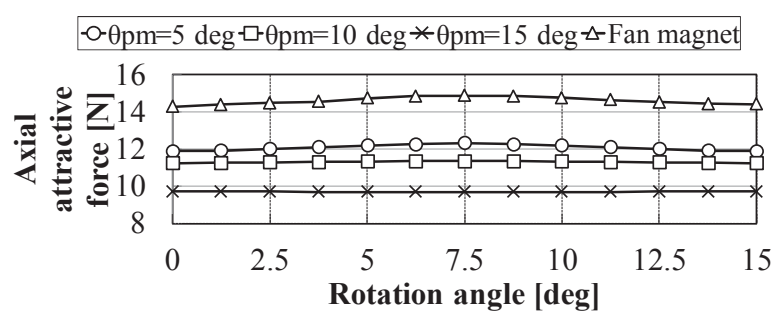

(b) Axial attractive force.

Fig. 12 Cogging torque and axial attractive force with difference rotation angle.

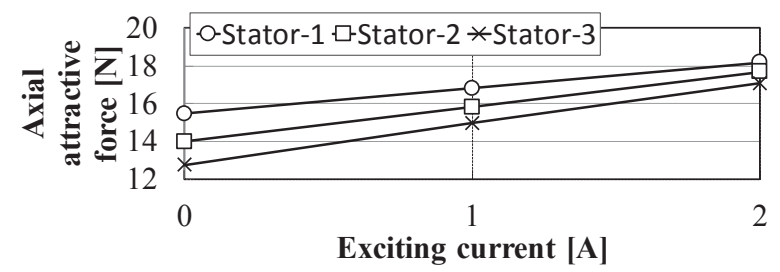

Fig. 13 Analysis result of relationship between axial attractive force and exciting current.

をFig. 12(a)とFig. 12(b)に示寸。コギングトルクの波高 值は切除角度が $10 \mathrm{deg}$ のときに最小となり $0.15 \mathrm{mNm}$ となった．軸方向吸引力変動は切除角度が大きくなる につれて減少した。一方, 切除角度が大きくなること で永久磁石総面積が減少するため, 軸方向吸引力の大 きさは小さくなった。以上の結果から，コギングトル クおよび軸方向吸引力変動を小さくでき，かつ高い軸 方向吸引力を得ることができる切除角度 $10 \mathrm{deg}$ の永久 磁石形状を本磁気浮上モー夕に採用した。 


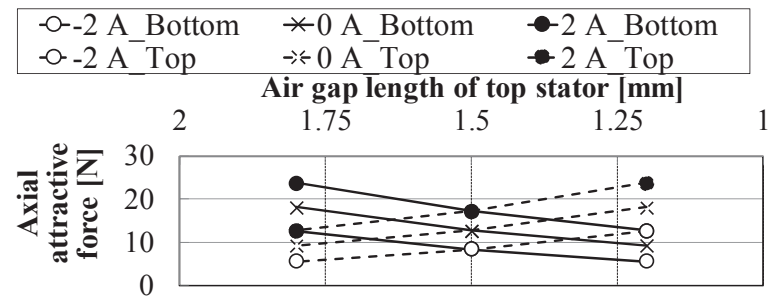

(a) Stator-1.

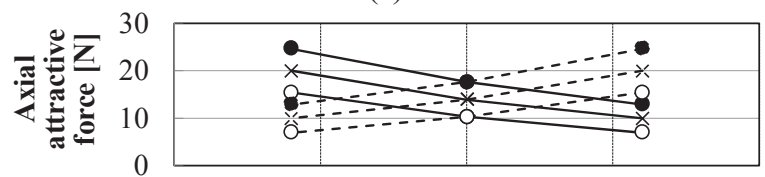

(b) Stator-2.

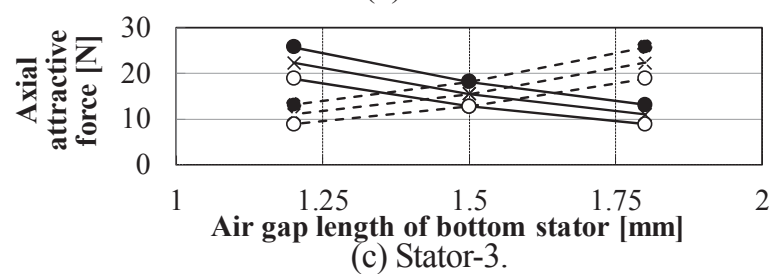

Fig. 14 Relationship axial attractive force and air gap length with difference stator pole model.

\subsection{2 ステータ突極形状の検討}

Fig. 13に励磁電流による軸方向吸引力の変化（解析 結果）を示す。力係数は Stator-1 で 1.3 N/A, Stator-2 で 1.8 N/A, Stator-3 で 2.2 N/A となった。励磁電流を 増加させても電流・吸引力の線形関係が保たれている ことより磁気飽和していないことが分かる。Fig. 14に 軸方向吸引力とエアギャップおよび励磁電流の関係を 示す。右上がりの破線で示すグラフはモータを組み立 てた場合の上部ステータの軸方向吸引力，左上がりの 実線で示すグラフは下部ステータの軸方向吸引力を示 している。上下のステータの軸方向吸引力曲線が交わ る部分が軸方向吸引力が釣り合っている点を示してい る。浮上中心から力が釣り合う点までの距離が可動域 を示しており, 最大励磁電流を $2 \mathrm{~A}$ とするとロータの 可動域は Stator-1 で士0.14 mm, Stator-2 で $0.22 \mathrm{~mm}$, Stator-3 で 0.30 mm である。式(4)からインペラがタッ チダウンから浮上するために必要な電流は Staotr-1 で 4.0 A, Stator-2 で2.6 A, Stator-3 で 2.0 A と算出された。 Stator-1 は突極面積が大きくコイル巻き数が少ないた め, 永久磁石の吸引力が大きく力係数が小さい。

Stator-3 では突極面積が小さくコイル巻き数が多いた め, 永久磁石の吸引力が小さい力係数が大きい。その ため, Stator-3 は Stator-1 と Stator-2 に比べ小さい励磁 電流でタッチダウンから浮上することができる。コイ ル抵抗によるジュール熱, ドライバ回路性能を考慮し て本磁気浮上モータの瞬間最大電流は $3.0 \mathrm{~A}$ を想定し

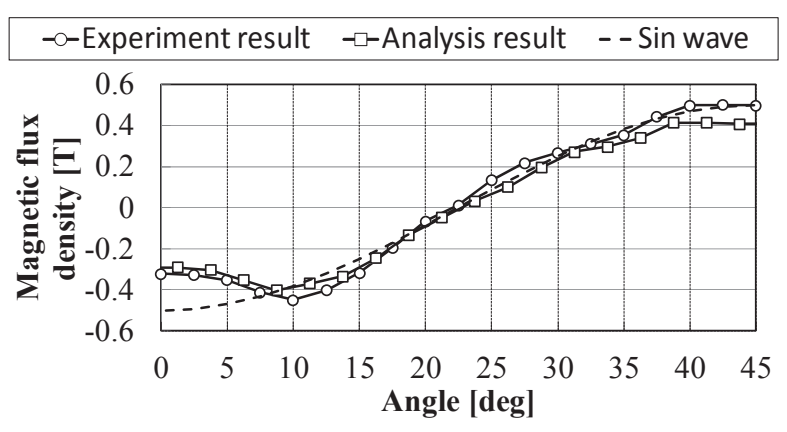

Fig. 15 Magnetic flux density distribution.

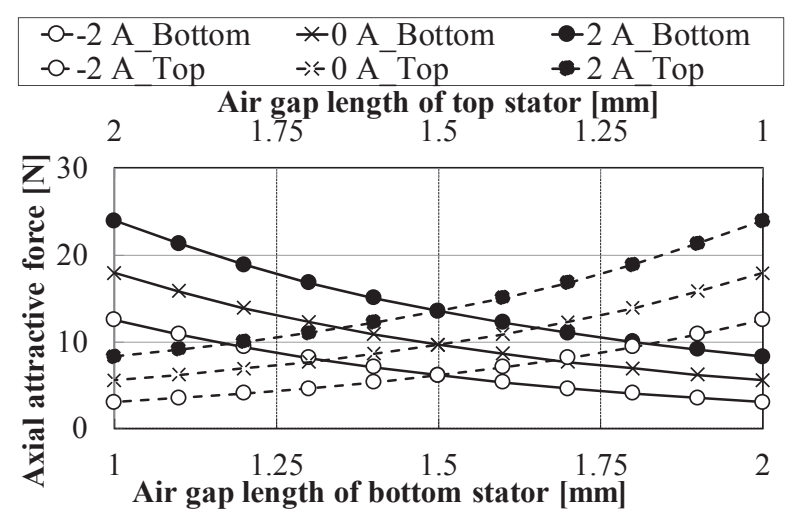

Fig. 16 Relationship between axial attractive force and air gap length.

ているため, ステータ突極形状はStator-3 を採用した。

3.2 小型磁気浮上モータの評価

\section{2 .1 磁束密度測定 $\cdot$ 軸方向吸引力測定}

Fig. 15に磁束密度分布の測定結果を示す。比較とし て 3.1.2 で示した切除角度 $10 \mathrm{deg}$ の解析結果と波高值 $0.6 \mathrm{~T}$ の正弦波（破線）を示寸。測定結果は波高值が $0.6 \mathrm{~T}$ で解析結果に比べ $0.1 \mathrm{~T}$ 大きい結果となった。ス テータスロットがある角度 $0 \operatorname{deg}$ 付近で磁束密度が若 干減少したが，全体的に正弦波に近い磁束密度分布を 実現できた。Fig. 16に実測した軸方向吸引力とエアギ ヤップおよび励磁電流の関係を示す。浮上中心である エアギャップ $1.5 \mathrm{~mm}$ では永久磁石の軸方向吸引力が $9.6 \mathrm{~N}$, 力係数が $1.9 \mathrm{~N} / \mathrm{A}$ であった。上下のステータに $2 \mathrm{~A}$ の励磁電流を流すことで最大 $\pm 0.3 \mathrm{~mm}$ ロータが変 位できることが分かる。タッチダウンから浮上するた めに十分な軸方向吸引力を発生可能である。Fig. 14(c) に示した解析結果と比較すると, 永久磁石の磁気吸引 力および力係数の実測結果が約 $20 \%$ 減少した。磁束密 度分布および磁気吸引力の解析結果と実験結果に差が 生じており，これはデバイスが小型であるため制作誤 


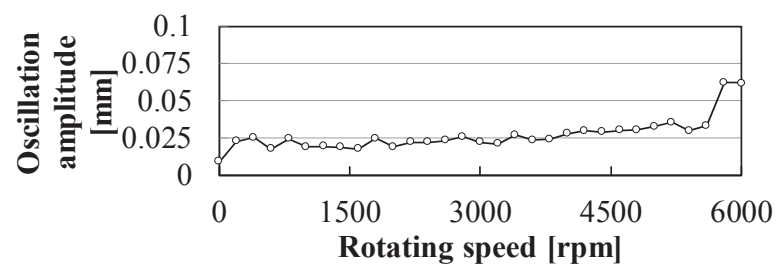

(a)Axial position Z.

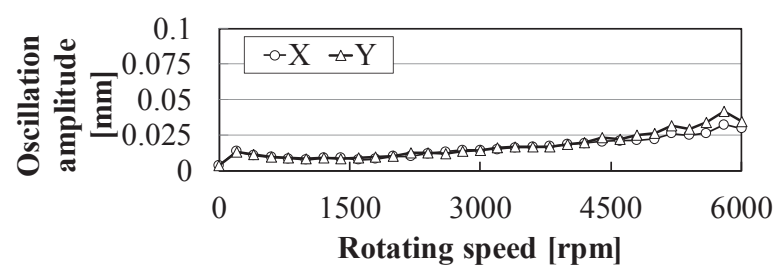

(b) Radial position $\mathrm{X} \cdot \mathrm{Y}$.

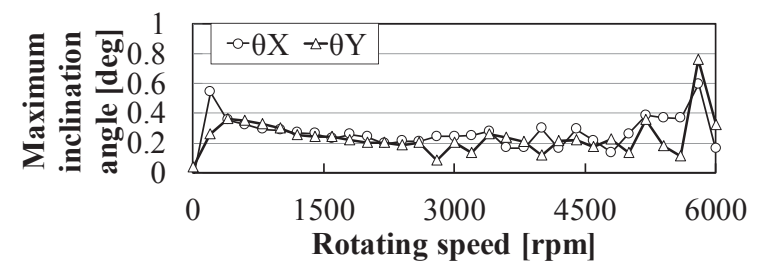

(c) Tilt angle $\theta_{\mathrm{x}} \cdot \theta_{\mathrm{y}}$.

Fig. 17 Oscillation amplitude of 5-DOF of levitated rotor.

差と測定誤差が大きく影響したと考える。しかし，今 後, 磁気浮上モータの改良を行うために¥の傾向を見 ることができ，有意義なデータであると考える。

\section{2 .2 浮上回転試験}

Fig. 17に各回転数における軸方向位置, 傾き角度, 径方向位置の最大振動振幅を示寸。製作した磁気浮上 モータで空気中で回転数 $6000 \mathrm{rpm}$ までの磁気浮上回 転に成功した。回転数 $4000 \mathrm{pm}$ において最大振動振幅 は軸方向位置 $0.028 \mathrm{~mm}$, 傾き角度 $0.29 \mathrm{deg}$, 径方向位 置 $0.018 \mathrm{~mm}$ であり, 各自由度において十分に小さい 振動振幅で制御できた。

今後, 製作した磁気浮上モータを小型遠心ポンプに 組み込み, 送液時のインペラの浮上安定性について評 価を行う。

\section{3 開発中の磁気浮上人工心臟の位置づけ}

現在, 臨床応用開始されている成人用補助人工心臟 の体積が 50 cc から 180 cc であるのに対し, 小児用人 工心臟は体積 $10 \mathrm{cc}$ 程度まで小型化が求められる。本 研究で開発した小児用人工心臓用 5 軸制御磁気浮上モ ータ試作機は, 体積 $25 \mathrm{cc}$ と目標サイズと比べて若干 大きいが，試作機として十分小型な磁気浮上モータを 製作することができたと考える。今後, 更なる小型化
を行う。また, 成人用補助人工心臓の駆動電力 $10 \mathrm{~W}$ から $15 \mathrm{~W}$ 程度に対して, 小児用人工心臟の目標駆動 電力が $2 \mathrm{~W}$ 程度であることからバッテリーサイズにつ いてもポンプ本体と同程度まで小型化が可能であると 考える。

\section{4 結言}

小児用補助人工心臓のための小型アキシャル型セ ルフベアリングモータを提案した。3 次元磁場解析を 用いてコギングトルクの小さい永久磁石形状を設計し た。製作した磁気浮上モータは小児用人工心臓に用い るために十分なロータの回転数と安定性を有すること を確認した。

(2014 年 3 月 14 日受付, 2014 年 10 月 5 日再受付, 2014 年 11 月 21 日再々受付)

\section{参考文献}

[1] 増澤 徹, 医療アクチュエーションの最前線, ヘルスケア とバイオ医療のための先端デバイス, pp. 316-325, 2009.

[2] 増澤 徹, 医用アクチュエーション技術に関する共同研究 委員会編 医用アクチュエーション技術の現状, 電気学会 産業応用部門リニアドライブ委員会, pp. 35-38, 2008.

[3] 小野稔, 補助人工心臟の現状と展望, 小児内科, vol.42, No. 5, pp. 784-788, 2010.

[4] Setsuo Takatani, Hideo Hoshi, Kennichi Tajima, Katsuhiro Ohuchi, Makoto Nakamura, Tadahiko Shinshi, Masaharu Yoshikawa, Feasibility of a Miniature Centrifugal Rotary Blood Pump for Low-Flow Circulation in Children and Infants, ASAIO Journal, Vol. 51, No. 5, pp. 557-562, 2005.

[5] David J. Farrar, Kevin Bourque, Charles P. Dague, Christopher J. Cotter, Victor L. Poirier, Design Features, Developmental Status, and Experimental Results With the Heartmate III Centrifugal Left Ventricular Assist System with a Magnetically Levitated Rotor, ASAIO Journal, Vol. 53, No. 3, pp. 310-315, 2007.

[6] 小西 義昭, 人工心臓 人工寸い臟, 日本機械学会誌, Vol. 107, No. 1033, pp. 6-9, 2004.

[7] 増澤徹, 体内埋め込み型人工心臟の設計, 設計工学, Vol. 36, No. 7, pp. 7-14, 2001.

[8] 丸山 修, 人工心臟(基礎), 人工臟器, 41 巻, 3 号, pp. 172-175, 2012.

[9] Daniel L. Timms, Nobuyuki Kurita, Nicholas Greatrex, Toru Masuzawa, BiVACOR A Magnetically Levitated Biventricualr Artificial Heart, Proc. of MAGDA conference in Pacific Asia, pp.482-487, 2011.

[10] Hideo Hoshi, Tadahiko Shinshi, Setsuo Takatani, Third-generation Blood Pumps With Mechanical Noncontact Magnetic Bearings, Artificial Organs, Vol. 30, No. 5, pp. 324-338, 2006.

[11] Masahiro Osa, Toru Masuzawa, Naoki Omori, Eisuke Tatsumi, Radial Position Active control of Double Stator Axial Gap Self-bearing Motor for Paediatric VAD, Proceedings of ISMB14, pp. 187-192, 2014. 